\title{
From Rice to Wheat: Irrevocable Effect of Drought on Rural Gender Roles in Upper Mesopotamia
}

\author{
Dilek Eroğlu \\ Department of Sociology, Abant Izzet Baysal University, Bolu, Turkey
}

Copyright $\bigcirc 2017$ by authors, all rights reserved. Authors agree that this article remains permanently open access under the terms of the Creative Commons Attribution License 4.0 International License

\begin{abstract}
This study questions the effects of climate change on gender roles in rural areas. The data was obtained from women's focus groups situated in 12 villages of Hasankeyf area which is located in Dicle basin of the Southeast Anatolia Region of Turkey. Through the research, it is brought into light that the structure of crop production is shifting from irrigated farming to dry farming like rice to wheat and mainly the women in rural areas are affected by climate change. Because of drought, seasonal migration is common to men and gender roles are shifting in agriculture. There is feminization in agriculture as drought increases.
\end{abstract}

Keywords Gender, Feminization in Agriculture, Climate Change, Participatory Rural Appraisal, Drought, Tigris Basin, Hasankeyf

\section{Introduction}

Climate change is one of the greatest issues in the world facing on a global basis. Especially in the post-industrial era during which fossil fuels became commonly used, changes in the land structure, deforestation and industrial processes, greenhouse gas accumulation in the atmosphere occurred, thus effecting the chemical properties of the atmosphere and causing global warming, hence climate change in the long term. All areas of life such as urban life, development and economy, technology, human rights, food and agriculture, clean water and health are affected by climate change (Ministry of Environment and Urbanization, 2012)

United Nations' specialist institution on its Intergovernmental Panel on Climate Change, on its Fifth Report (WGI; AR5), clearly states that, as in a case that eluded from the concept of probability, by the rate of " $95 \%$ ", climate change today is "an indisputably human sourced issue". Climate change is an issue which will find a place not only in environmental policies but also in agriculture, health, economy, human rights policies, and even in military action policies (IKV Report, 2013). Supporting these remarks, there are theories that various social movements in the Middle East in our century are based on long-term decrease in productivity due to climate change, related poverty and immense movements of migration. The period from 1983 to 2012 was likely the warmest 30 -year period of the last 1400 years in the Northern Hemisphere. Evidence of observed climate change impacts is the strongest and most comprehensive for natural systems. In many regions, changing precipitation or melting snow and ice are altering hydrologic systems, affecting water resources in terms of quantity and quality. Assessment of many studies covering a wide range of regions and crops shows negative impacts of climate change on crop yields (IPCC Fifth Assessment Report, 2014).

The concept of climate chance caused by intensive human activities affects human beings and all eco-systems negatively. Climate change has remarkable effects on food safety, food accessibility and stability of the whole food system.

No country in the world by which we are fed and on which we live can exclude itself from the effects of climate change. Therefore it must be set as a common target to cope with the change in real-time and prevent further change. By the Paris Agreement, countries have decided to take common action against climate change.

The increasing temperature of the planet and corresponding changes in the climate come to light in different ways. On one hand, they cause extraordinary climate events such as whirlwinds, hurricanes, floods and drought; on the other hand, they lead to loss of animal species and plantation.

In 1998, the population migrating due to drought, flood, forest destruction and infertility of lands had reached 25 million, two times the number of people who had to migrate due to wars in the same year from one land to another. Today, around $58 \%$ of refugees are considered as climate refuges (Alphan, 2016).

Climate change has negative social effects all around the world; however, women are more vulnerable than the men in this context especially who lives in rural areas. This is 
because less than $10 \%$ of the world's landholders are women, but women are the core labor and knowledge source in agriculture. On average, women cover $43 \%$ of the agricultural labor force in developing countries; almost $70 \%$ in South Asia and more than $60 \%$ in sub-Saharan Africa (FAO, 2010, 2011).

Despite the fact that women are producing around $45-80 \%$ of the overall production of the world and women are more successful during the wars in regard to their food security knowledge and skills of keeping their families alive and finding food (Goldstein, 2005), women are in a disadvantageous position in most climate related disaster areas due to limited access to information and public services.

The most vital negative effects of climate change are drought and lacking water sources for both human and agricultural use. Irregular rainfall may also lead to floods, forest fires and changes in ecosystems in the world, as well as in Turkey.

An attention to gender dynamics, moving populations (e.g., seasonal agricultural workers), and disadvantaged communities (e.g., gypsies) through the lens of climate change adaptation is critical to understand the shifting context of marginality and vulnerability of both humans and nature, and thus, to achieve sustainable rural livelihoods. Scholars caution, though, not to romanticize women, women's knowledge, or women's participation in climate change adaptation but to recognize their roles, responsibilities, constraints, and opportunities (Sultana 2014, Carr and Thompson 2014, Eroglu and Atalan-Helicke, 2016).

In some studies in the literature, it was highlighted that climate change also increases vulnerability of women through male out-migration that increases the workload of women (Chindarkar, 2012), gender division of labor (Lambrou and Paina, 2006) and access to resources (fuelwood and water) (Tandon, 2007). It was also reported that climate change increases social conflicts on natural resources (Omolo, 2011).

\section{Methodology}

According to Chambers and Conway (1992: 7-8), a livelihood is sustainable when it can "cope with and recover from stresses and shocks, maintain or enhance its capabilities and assets, while not undermining the natural resource base." Sustainable livelihood covers different dimensions of human life which are natural, economic, human, social and environmental capital. In this study, a sustainable livelihood approach was used to understand the effects of drought on gender roles in rural Turkey.

The study was conducted in May, 2015. 12 villages were under research. In the research area also 2 more villages that were empty because of mass migration from rural to urban areas. Total population of those villages was 3558 . There were 1761 men and 1792 women in these areas, which shows small amount of excess women population.

In this study, participatory rural analysis tools such as calendars, maps, graphs were used in 10 different focus groups. In each focus group, 10 to 15 women were present. Additionally, as a secondary information source manager, village headmen (mukhtar) and cooperative members were interviewed to cover potential information gaps.

During "transect walk", all household were also visited and the women were invited to group meetings. Apart from willingness, no limitation criteria such as age, agricultural activities etc. were set for participation. During the focus group meetings, all information and maps were written jointly by the group. All data were then analyzed and reported.

\section{Results and Discussion}

\subsection{Demographic Structure and Migration}

Hasankeyf is one of the districts of Batman province which is located by the Tigris Rivers. The area is subject to Ilisu Dam that is one of the projects in the Southeastern Anatolia Regional Development Project. Hasankeyf is a significant historical location for many civilizations and some of the ruins are still standing by Dicle River.

Today, rural population is higher than urban population according to the development agency's report (70/30) but it is expected to go down from $29 \%$ to $20 \%$ because of migration from rural to urban areas. As stated on the same report, Batman's economy mainly depends upon agricultural production and villages investigated during the field study were found to reflect this fact in general.

Table 1. Population in the villages

$\begin{array}{llll}\text { Village Name } & \text { Total } & \text { Men } & \text { Women } \\ \text { Akalın } & 264 & 122 & 142 \\ \text { Aksu } & 240 & 119 & 121 \\ \text { Bayırlı } & 39 & 18 & 21 \\ \text { Irmak } & 330 & 161 & 169 \\ \text { Karaköy } & 345 & 152 & 193 \\ \text { Kumluca } & 50 & 22 & 28 \\ \text { Öğ̈utlü } & 120 & 57 & 63 \\ \text { Saklı } & 345 & 175 & 170 \\ \text { Tepebaş1 } & 218 & 106 & 112 \\ \text { Uzundere } & 138 & 67 & 71 \\ \text { Yolüstü } & 170 & 104 & 66 \\ \text { İncirli } & 133 & 62 & 71\end{array}$

Total population of Hasankeyf province is 6748 and the rural population corresponds to 3558 people, 1761 of which are men and 1797 of which are women. There are 2392 people in the research area, 1165 men and 1227 women. When the population structures of the connected villages are considered in terms of sex, the number of women in villages turns out to be higher than the number of men. Despite the population changes in the rural areas due to migration 
movements, it is found that women's ratio is higher even at present. All women in the villages are involved in agricultural production. According to reports, this ratio is $92 \%$, in Batman in general. Each village had seasonal population changes. Men work outside the villages at least for 8 months a year to find jobs in different parts of Turkey. They work mostly in agriculture, construction and the tourism sector as unqualified workforce. As a result of primary and secondary data, it may be mentioned that agricultural feminization is valid in each village.

In terms of livelihood activities, there were 2 groups of families in the villages. First group consisted of few households, 1 or 2 in each village, who were rangers but still dependent on agricultural production. Rest of the population relied only on agricultural production, income of these households was unstable throughout the year, and they depended on seasonal migration.

Number of child per household varied between 3 and 12 . Average number of child per household was determined to be 7-8. These data confirms the report prepared in 2013 by the Regional Development Agency. It was also determined that households in the villages were often big families and elders (65 and older) were living within each household.

Polygamy is not a common cultural practice in those villages. Only 1 and rarely 2 such households were determined. In these cases, it was normalized by women in focus groups. Statements such as "polygamy is necessary if a woman cannot give any children to a man" were pointed out in all focus groups.

Women's marriage age reached down to 15 . The women who took part in focus groups who were older than 40 was determined to marry in their 15-year-olds, while in most villages, it was pointed out that the age of marriage increased and birth rate decreased. It was also determined that young women thought marriage is useful tool to migrate from the village to the city. Young women pointed out that they do not make the choice to get married unless the proposal came from someone who is leaving the village.

Karaköy and Saklı villages had young populations that were the most active in the communities. However, increasing rates of seasonal migration and education, as it is for Turkey in general, increases the migration rate. This also results with aging rural areas. This situation was also confirmed in women's focus group meetings.

It was clear that migrating from rural to urban areas was the main focus in all villages, but in this study, pushing effects of villages were investigated. Primary reason behind migration was summarized by the women as "loss of water sources and streams". It affects all households in the same way. Water scarcity is a common source of economic loss in the area.

Among the villages, only Ögütlü and Karaköy stated that they did not have water issues; however, it was determined that even those villages were lacking water because of drought, but the population had not felt the scarcity yet, due to the higher migration rate.
Population movement in the village was summarized by a woman as follows; "when people migrate from the village they never come back. Whoever remains in it is either hopeless or old."

\subsection{Livelihood Analyses}

Agriculture is the core economic activity in all villages. Since 2010, crop production (rice, vegetables and fruits) has still been the main production. There was 1 stream for irrigation. It was stressed by all villages that in the last 5 years, the stream lost most of its water and villagers had to shift their agricultural production from irrigated farming to dry farming. Drought influenced all production patterns in the villages, which also directed effects onto income generation and gender roles as social capital.

Animal Breeding is also common agricultural practice and marketing of sheep and goat products like cheese, yoghurt and butter are important income generating activities in all villages. Animal breeding is a woman's task. Men only function when contacting the veterinary or in marketing of living animals. Despite this fact, when asked "whose job is animal breeding," the women replied "the man's job". Women collect and produce different traditional milk products. After separating family consumption, they then send products like cheese, yoghurt to small scale local shops of Hasankeyf. Men control the entire financial process. The incomes from the subsistence activities such as field crops, sheep, goat etc. are under the control of men. There is only one type of animal production and its income belongs to women in those villages: turkey and chicken breeding.

There are no presently active facilities of animal breeding and no agricultural extension or training program in the villages. Hiring shepherds is a common practice in 3 highland villages.

Even if the workload of women was observed to be more than that of men, it was observed that hiring shepherds remarkably reduced the workload of women. Households prefer hiring a shepherd on tasks that generate revenue. As the number of animals goes lower and when the herd is rather meant for the household's consumption, families take care of their animals themselves.

At present, there is production of vegetables (tomatoes, pepper, and eggplant) and fruits (grapes, berry, peach, pomegranate, chestnut, and fig) meant for household's own consumption. During the interviews made with the women, it was seen that both fruits and grape leaves were utilized. Grape leaves are pickled in every village by women and the surplus is sold to relatives. The leaves are often dried. After harvesting the grape, women dip the grape into water with some ash and then it is spread for drying.

Except for Uzundere village, drying fruits and vegetables is made on roofs. In Uzundere village, people dry grapes on soil as they believe the outcome is different. There are no facilities to dry fruits and vegetables neither around Hasankeyf nor in the villages, and there has been no 
training/publishing campaign in the region. The present state report for the sub-region suggests that Batman can use solar-power 172 days a year and 7.5 hours a day. However, except for drying the fruits and vegetables, there is no benefit of renewable energy sources like sun and wind, towards reducing the production costs in the villages.

Pickled leaves, cheese, yoghurt, eggs, dried grapes are the products the women produce, the amount depending on the yield of the year, and the market which they reach through their relatives. As for Aksu-Tepebaş1-Uzundere basin, products in question include sumac as well. Sumac is collected by women and marketed by men. There is no facility about sumac plant in Hasankeyf or in the villages.

All the bread consumed in the villages is made by women in floor furnaces (tandir). In only one of the villages, each house has its individual floor furnace. As for the other villages, every 3-4 houses have one floor furnace; therefore shared use is the practice. Constructors and materials for building floor furnaces are available in Batman but not in Hasankeyf. Wheat flour for bread making is obtained from the wheat growing in villagers' own fields. Conversion of the wheat into wheat flour is made in Batman. It was stated that in the past, especially mountain villages that have little land, people used to obtain wheat flour from small scale local shops of Hasankeyf through barter. Most of the time, barter was made with yoghurt. The villagers received wheat flour subsidies if they were too poor or too old to grow their own wheat.

Poultry farming is a common practice in each household. Chicken, turkey and egg revenues belong to women. In every village, women collect some herbs from forestry areas, while it is used only for household consumption. Villagers' relation to the forest is based on consumption. Wood, herbs, wild plants are collected for household consumption and animals are brought out to graze in the forest areas. Forest areas mainly contain oak trees. It is the fact that marketing of agricultural products, lack of extension services, lack of knowledge on renewable energy are serious problem areas for sustainable livelihoods.

\subsection{Social Capital and Networks}

There is a strong connection among relatives in all villages. This situation is functional, especially regarding the marketing of the subsistence products, establishment of seasonal work-connections, education, financial relations, health and monetary aid aspects. This connection is sustained among the villages, as well relatives.

Sakl1 village has a remarkable position in the relationship among the villages. Sakl1 village has a secondary school. For example, in an occasion like a wedding, Saklı village is reported to invite the neighboring villages (Irmak, Büyükdere, İncirli) as well and throw a common entertainment event. Sakl1 village sells vegetables to Irmak village. As for relations with the institutions, there are notable relationships with district governorship and the public education center. Presence of an active provincial district governor is a reason behind these relationships.

The women have no connection to district governorship, because this relationship is provided through men. Only in Aksu village, district governorship tried to establish a communication platform with women and it was seen that this has not become a sustainable social connection yet. Women's most notable relation is to public education centers. This bridge is established via the center's offers of Qoran courses, reading and writing, child care, and wood painting. However, these training occasions are offered by village headmen (mukhtar), therefore, the connection here is not established through a social network, but through individual relations. Women of the 2 villages (Karaköy and Aksu) earn some money via Turkish Employment Agency (İŞKUR) projects by wood-painting and making souvenirs; however, it is uncertain whether this project is sustainable.

There are no long-term conflicts in the area but mainly 3 subjects are open to conflict in all villages: 1. Village headman (mukhtar) elections; 2. Water use and sharing; 3. Management of village pastures. Especially during the season of mukhtar election, when there are two candidates, this is a cause of partition among the villagers. However, when the elders intervene in, the conflicts are resolved. Only the Yolüstü village is in continuous conflict which is due to new settlers. The women stated that they do not talk to each other at all, and when asked "what do you do when you see each other on the road?" they replied "we just greet each other but do not talk to each other, we live like two separate villages." The conflict is escalated by limitation of income-generating activities, especially through (common) use of lowland/pasturage areas. This is because the grass output of the pasturage areas is reduced by increasing drought.

In all villages, women are not allowed to communicate directly with men. Women are also not allowed to use cellars. Interviewed villages did not specify any limitation towards the use of cell phones by women, but the women in Üçyol village highlighted that they are not allowed to use cellphones or the internet. Internet is not a media involved in women's lives in any of the villages. The most common type of media (by an average of 4 hours per evening) is television.

There are 2 villages where the relations among the women are the strongest. One is Karaköy, where there is a shrine and every year on 7th of March the women feast here, bringing what they have cooked and following mawlid/Islamic memorial ceremonies. The other one is Uzundere village, where the women gather for a mass picnic, perform folk dances and play what they call a "stone game" where they try to hit a standing stone throwing large stones. Again in the same village, the women have protested against water cut-off due to unpaid electricity bills. During the protest, the women did not send their children to school and made 7-8 teachers visit their homes. These two villages are recommended to be chosen as pilot villages for a campaign supporting women in the future. 
There are no known cooperatives or unions established by women among the interviewed villages. The women have not heard of any association or cooperative that would provide collaboration or technological support for them.

Organization structure is rather male dominant, predominated by village headmen. None of the community councils include women and there are no further structures established for women's participation.

Villages' organized structure shows up in different fields;

Rotational use of irrigation water and tap water:

1. Where the shepherds are unavailable; rotational pasturing is organized. For each cattle, it is 1 day of herding, and it is 1 day of herding for every 4 sheep/goats in the particular village's herd.

2. Mass cooking and food distribution by women for participants of religious ceremonies.

3. Mass picnic and entertainment among women.

4. Mass cooking and distribution in case of funerals.

Women's participation in decision-making is limited to the village. As for more major issues such as the Ilisu Dam issue or any other decision-making processes like sub-district based issues, it doesn't exist. Every sort of decision mechanisms are under control of the men.

The technologies used by the men in the villages are cars, cellphones, minibuses and the internet in the case of young men. There are no internet cafes in the interviewed villages. Animal breeding at each village is performed dominantly by the women and there are no relevant technologies in the villages, particularly the milking machine. The only milking machine is understood to be in Irmak Village's previous village headman's house. It was observed that every village has laundry machines, but only a few houses have dishwashers. Doing the dishes is one of the jobs helped by the children and younger women. Except for a few houses residents of which are over 70 years of age, every house in the village has a TV, and mobile phones are not used.

It was stated that water resources at each one of the interviewed villages have dried up and agricultural manufacture patterns have remarkably changed. The most important example is that rice used to be grown in previously mentioned 5 villages, but now it is only possible to grow wheat. Rice grows in water and its economic value is higher than that of wheat. As for growing vegetable and fruits which require watering; households stated that they grew such products only for the household's consumption in the last 5 years because of water shortage. Due to increasing drought in each village, underground water is extracted and electricity bill for drilling for water is a major issue among the villages. Despite the fact that Ilisu Dam is not active yet, water resources dried up by ever-increasing drought and this made water turn into a "commodity". This is a subject of "conflict" both among the households of the villages and in the relations with the local government.

\subsection{Gender Roles}

Gender roles have similar characteristics in all villages. The private sphere is under the responsibility of women. Cleaning the house, taking care of children and the elderly, dish-washing, laundry and cooking are accepted as the responsibilities of women. In addition to these, women are responsible to take care of any kind of animals. They are responsible for cleaning shelters, milking, and feeding the animals. When the affairs of the household should be carried to the public sphere, men step in. A good example of this is that, in animal breeding where almost everything is taken care of by women, veterinary services to be received from outside the village are accepted as the man's responsibility. Moreover, in cases of large herds of goats, sheep and cattle, the control is taken over by men. Men assign these large herds to shepherds with yearly contracts. These shepherds who come from different cities in the Southeast Anatolia Region stay with their families in a house in the village sustained by the villagers and their families.

Taking care of poultry (chickens, turkeys, etc.) is also in the hands of women. However, this is the only item of income that is not under the control of men in the household. Maintenance, purchase, sale and income of poultry belong entirely to women. Working hours of women in all villages start between 5 and 6 o'clock in the morning.

While plant production in the village is normally the mutual job of men and women where they work together in fields, all of such jobs have become the responsibility of women due to seasonal migration of men in the last 5 years. Participants all villages stated that especially the end of rice production they sustained up to 10 years ago, reduction in their income and obligation of men to migrate for seasonal jobs are serious issues. The data obtained with focus groups revealed that gender roles are changing in villages and the work load of women in the village is increasing.

\section{Conclusions}

The purpose of this study is to discuss drought in rural areas and the related changes in gender roles. The obtained findings show that there is drought in the research area due to climate change and this drought affects the sources of income, migration movements and gender roles of the people living in rural areas. The migration created by drought in the research area is leading to feminization in agriculture.

The study also shows that effects related to climate change started on the level of rural areas in Turkey. This effect has 4 significant outcomes;

1. Plants with high demand for water can no longer be produced in the rural areas, and the villagers turn to plants known to be drought-resistant, mostly wheat or barley, as a way of adaptation.

2. With the reduced amount of water, conflict arises in all levels in the village and in institutions. 
3. The decreasing yield and lack of income-producing activities trigger seasonal migration. While this leads to feminization of agriculture, men are also forced to migrate due to the effects of gender roles. They work in cities they do not know, do jobs they do not know, and mostly undocumented, lacking social security.

4. Seasonal migration is increasingly turning into rural-to-urban migration.

As shown in various studies and reports, women in this cluster of problems are more vulnerable to climate change due to numerous issues including increased work load, higher poverty and basic rights like food security and health. This study also shows that women are heavily left alone with all these social, economic and environmental problems in rural areas.

Migration is an irrevocable outcome of climate change, and as in the examples of conflict in some countries, the abandoned lands carry the risk of sustaining the social burdens of climate change heavily.

Considering these findings, support programs are immediately needed for rural communities living in areas with risk of drought, or flood or irregular rainfall, especially like regions in Turkey located in the Mediterranean climate zone.

Marginal Communities like Hasankeyf villagers are suffering from technological limitations and low access to expansion services and the market. It is known that most climate-related rural effects result in migration. This has been confirmed in this study, but there is need for further research in rural areas. In order to increase the resilience of rural communities against climate change, more researches should be broadened on all levels and strategies that will increase rapid adaptation should be supported. Feminization of rural areas should be taken into account while determining such strategies, and it is indispensable to centralize women's connection to the nature and local knowledge in this re-established nature-human relationship.

\section{Acknowledgements}

I am thankful to Hasankeyf Governorship and Hüsnü Özyeğin Foundation who contributed in realization of the study here.

\section{REFERENCES}

[1] Turkish Ministry of Environment and Urbanization, (2012),
Climate Change Action Plan, Available On line, https://www.csb.gov.tr/db/iklim/banner/banner591.pdf

[2] İKV Publications, (2013), Kyoto Climate Change Proceedings Towards 2010: AB's sufficiency and Turkey's position, İktisadi Kalkınma Vakfi Publications, Publ. No: 268, Istanbul

[3] IPCC Fifth Assessment Report, 2014, Available online, https://www.ipcc.ch/report/ar5/

[4] Alpman, M., (2016), Cari açık açılır, kapanır Cerattepe yarası kapanmaz", Miliyet Newspaper, http://sosyal.hurriyet.com.tr /yazar/melis-alphan_350/cari-acik-acilir-kapanir-cerattepe-y arasi-kapanmaz_40058332

[5] United Nations, 2016, http://www.un.org/womenwatch/featur e/ruralwomen/facts-figures.html

[6] Chindarkar, N.,( 2012), Gender and climate change-induced migration: proposing a framework for analysis, Environmental Research Letters, 7 (2012), 7 pp, http://iopscience.iop.org/article/10.1088/1748-9326/7/2/0256 $01 / \mathrm{pdf}$

[7] Sultana, F., (2014) Gendering Climate Change: Geographical Insights, The Professional Geographer, 66:3, 372-381

[8] R.A.Carr, and C. M., Thompson, (2014), Gender and Climate Change Adaptation in Agrarian Settings: Current Thinking, New Directions, and Research Frontiers, Geography Compass, 182-197

[9] Goldstein, D., (2005), Women Under Siege, (From Betty Crocker to Feminist Food Studies: Critical Perspectives on Women and Food ), 299 pp

[10] Eroglu, D., and Atalan-Helicke, N., 2016, Rural Livelihoods and Terrestrial Snail Harvesting in Turkey, World, XIV World Congress of Rural Sociology, Canada

[11] Lambrou, Y., and Paina, G., (2006), Gender: The Missing Component of the response to climate change, United Nations Food and Agriculture Organization Gender and Population Division Sustainable Development Department Report, 44pp

[12] Tandon, N. (2007). Biopolitics, climate change and water security: Impact, vulnerability and adaptation issues for women. Agenda: Empowering Women for Gender Equity. 73, 4-17.

[13] Omolo, N. A., (2011), Gender and climate change-induced conflict in pastoral communities: Case study of Turkana in northwestern Kenya, African Journal of Conflict Resolution, $10(2), 81-102$

[14] Chambers, R. and Conway, G. R., (1992), Sustainable Rural Livelihoods: Practical Concepts for $21^{\text {st }}$ Century, IDS Discussion Paper 296

[15] IKV Report(2013), Kyoto-Type Climate Change Negotiations towards 2010: the EU's Competency and Turkey's Position," Economic Development Foundation (IKV), publication no: 268, Istanbul, December 2013 